\title{
PENGEMBANGAN INSTRUMEN KEMAMPUAN BERPIKIR KRITIS DAN LITERASI HUMANISTIK PADA PEMBELAJARAN IPA KELAS V SD
}

\author{
J. Harta ${ }^{1}$, I.B.P. Arnyana ${ }^{2}$, N.K. Suarni ${ }^{3}$ \\ Program Studi Pendidikan Dasar \\ Universitas Pendidikan Ganesha \\ Denpasar, Indonesia \\ e-mail: juniharta52@gmail.com ${ }^{1}, \underline{\text { putu.arnyana@undiksha.ac.id }}{ }^{2}$,
}

\begin{abstract}
Abstrak
Penelitian ini bertujuan untuk mengetahui dan mendeskripsikan validitas dan reliabilitas instrument kemampuan berpikir kritis dan literasi humanistik pada pembelajaran IPA kelas V SD. Penelitian ini merupakan penelitian pengembangan pendidikan (educational research and development) dengan desain penelitian 4D (four-D). Subyek pada penelitian pengembangan ini meliputi 2 dosen ahli dan 3 praktisi (guru).Teknik pengumpulan data yang digunakan yaitu rubric penilaian judges. Berdasarkan analisis data, diperoleh hasil penelitian bahwa : (1) Instrumen kemampuan berpikir kritis yang dikembangkan memenuhi syarat validitas konten dengan nilai 0,88 dengan kategori sangat baik dan sangat layak digunakan, (2) Instrumen literasi humanistik yang dikembangkan memenuhi syarat validitas konten dengan nilai 0,86 dengan kategori sangat baik dan sangat layak digunakan, (3) Instrumen berpikir kritis yang dikembangkan memenuhi syarat reliabilitas dengan nilai 0,674 dengan kategori tinggi, (4) Instrumen literasi humanistik yang dikembangkan memenuhi syarat reliabilitas dengan nilai 0,656 dengan kategori tinggi sehingga layak digunakan dalam pembelajaran.
\end{abstract}

Kata Kunci : Berpikir Kritis; Literasi Humanistik

\section{Abstract}

This study aims to determine and describe the validity and reliability of the instrument of critical thinking skills and humanistic literacy in science learning in fifth grade elementary school. This research is an educational development research (educational research and development) with 4D (four-D) research design. The subjects in this research development include 2 expert lecturers and 3 practitioners (teachers). Data collection techniques used are judges assessment rubric. Based on data analysis, the results of the study are as follows: (1) The developed critical thinking skills instrument meets the requirements of content validity with a value of 0.88 with a very good category and is very feasible to use, (2) The developed humanistic literacy instrument meets the content validity requirements with value 0.86 with a very good category and very feasible to use, (3) Critical thinking instruments developed meet the reliability requirements with a value of 0.674 with a high category, (4) Humanistic literacy instruments developed meet the reliability requirements with a value of 0.656 with a high category so that it is feasible to use in learning.

Keywords : Critical Thinking; Literacy Humanistic

\section{PENDAHULUAN}

Pendidikan merupakan tempat untuk meningkatkan dan mengembangkan kualitas sumber daya manusia. Melalui penyelenggaraan pendidikan diharapkan dapat mencetak manusia-manusia berkualitas yang akan mendukung tercapainya sasaran pembangunan nasional. Untuk dapat mewujudkan pendidikan yang berkualitas, maka pengembangan pendidikan pada Abad ke 21 harus dilaksanakan dengan berstandar pada empat pilar pendidikan sebagaimana yang telah direkomendasikan oleh UNESCO yaitu learning to know, learning to do, learning to be, dan learning to live 
together. Melalui empat pilar tersebut peserta didik diharapkan dapat tumbuh menjadi individu yang utuh, yang menyadari segala hak dan kewajiban, serta menguasai ilmu dan teknologi untuk bekal dan kelangsungan hidupnya serta kelestarian lingkungan alam tempat kehidupannya (Dantes, 2017:12-13).

Pada era sekarang dalam revolusi industry 4.0 pendidikan telah memasuki babak baru dalam perkembangan ilmu pengetahuan dan teknologi yaitu perlunya mengembangkan literasi baru. Literasi baru mencakup literasi data, literasi manusia, serta literasi teknologi. Literasi data terkait dengan kemampuan membaca, menganalisis berdasarkan data dan informasi, literasi manusia terkait dengan kemampuan komunikasi, berpikir kritis, kreatif dan inovatif , dan literasi teknologi berkaitan dengan kemampuan memahami cara kerja mesin (Sanjayanti, 2018). Literasi humanistik menjadi hal yang penting dalam menghadapi pendidikan yang telah memasuki Abad 21, karena tujuannya adalah manusia bisa berfungsi dengan baik dilingkungan manusia dan dapat memahami interaksi dengan sesama manusia (Sanjayanti, 2018). Keterampilan literasi yang baik akan berpengaruh penting dalam membantu generasi muda untuk memahami informasi baik berupa lisan maupun tulisan. Tumbuhnya keterampilan literasi humanistik pada diri siswa harus didukung juga dengan memiliki kemampuan berpikir kritis pada anak tersebut.

Kemampuan berpikir kritis merupakan proses berpikir secara intelektual dengan menggali informasi melalui proses analisis dan proses evaluasi terhadap informasi yang didapatkan menjadi sebuah kesimpulan. Menurut Walker (dalam Ismaimuza, 2010) berpikir kritis adalah suatu proses intelektual dalam pembuatan konsep, mengaplikasikan, menganalisis, menyintesis, dan mengevaluasi berbagai informasi yang didapat dari hasil observasi, pengalaman, refleksi, di mana hasil proses ini digunakan sebagai dasar saat mengambil tindakan. Dengan berpikir kritis siswa dapat meningkatkan pengetahuan kognitif dalam proses pembelajaran. Hal tersebut dapat diwujudkan melalui pendidikan khususnya pada pendidikan Sekolah Dasar.

Pendidikan merupakan unsur utama dalam pengembangan manusia seutuhnya, maka pengelolaan pendidikan harus berorientasi kepada bagaimana menciptakan perubahan yang lebih baik. Salah satunya upaya itu di tempuh dengan menerapkan kurikulum 2013 yang disusun dengan dilandasi pemikiran tantangan masa depan yaitu abad ke 21 . Undang Undang Nomor 20 Tahun 2003 Tentang Sistem Pendidikan Nasional Pasal 1 butir 19, menjelaskan kurikulum adalah seperangkat rencana dan pengaturan mengenai tujuan,isi, dan bahan pelajaran serta cara yang digunakan sebagai pedoman penyelenggaraan kegiatan pembelajaran untuk mencapai tujuan pendidikan tertentu.

Pembelajaran kurikulum 2013 mendasarkan pada konsep bahwa pembelajaran merupakan suatu proses pengembangan potensi dan pembangunan karakter setiap peserta didik sebagai hasil dari sinergi antara pendidikan yang belangsung di sekolah, keluarga dan masyarakat. Proses Pembelajaran Kurikulum 2013 tersebut memberikan kesempatan kepada peserta didik untuk mengembangkan potensi mereka menjadi kemampuan yang semakin lama semakin meningkat dalam sikap, pengetahuan, dan keterampilan yang diperlukan dirinya untuk hidup dan bermasyarakat. Pembelajaran kurikulum 2013 ditujukan untuk mengembangkan potensi peserta didik agar memiliki kemampuan hidup sebagai pribadi dan warga negara yang beriman, produktif, kreatif, inovatif, dan efektif, serta mampu berkontribusi pada kehidupan masyarakat, berbangsa dan bernegara. Salah satu muatan pelajaran yang terkandung dalam kurikulum 2013 di Sekolah Dasar adalah Pembelajaran IPA.

Pembelajaran IPA merupakan suatu proses dan rangkaian untuk mempelajari peristiwa-peristiwa yang terjadi di alam dengan melakukan observasi, eksperimentasi, penyimpulan, penyusunan teori agar siswa mempunyai pengetahuan 
gagasan dan konsep tentang alam sekitar. Menurut Supriyadi (2009:3) menjelaskan bahwa IPA adalah suatu cara berpikir untuk memahami suatu gejala alam, suatu cara untuk memahami gejala alam, dan sebagai batang tubuh keilmuan yang diperoleh dari suatu penyelidikan. Salah satu tujuan pembelajaran IPA menurut BNSP (dalam Susanto, 2013: 171) yaitu mengembangkan keterampilan proses, rasa ingin tahu, sikap positif dan kesadaran tentang adanya hubungan yang saling memengaruhi antara IPA, lingkungan, teknologi, dan masyarakat. Oleh karena itu, dalam proses kegiatan belajar IPA sangat penting diterapkan untuk menambah pengetahuan siswa dan harus dilaksanakan sesuai dengan strategi yang tepat agar siswa dapat mudah memahaminya.

Pada proses pembelajaran IPA di Sekolah Dasar, seorang guru merupakan salah satu komponen yang berperan penting dalam menciptakan iklim belajar yang kondusif bagi siswa. Guru juga dituntut untuk terampil dalam merencanakan, melaksanakan dan mengevaluasi proses pembelajaran. Roestiyah (2008:1) menyatakan bahwa "guru harus memiliki strategi agar siswa dapat belajar secara efektif dan efisien untuk mencapai tujuan pembelajaran yang telah ditentukan". Sudah seharusnya pembelajaran yang dilakukan oleh seorang guru dapat memberikan motivasi belajar bagi siswa agar dapat mengembangkan kemampuan yang dimilikinya secara baik. Salah satunya dengan mengembangkan kemampuan berpikir kritis dan literasi humanistik yang dimiliki siswa. Pengintegrasian kemampuan berpikir kritis dan literasi humanistik ke dalam dunia pendidikan dan pembelajaran tematik diharapkan mampu meningkatkan kemampuan berpikir kritis dan literasi individu Indonesia.

Berdasarkan

pencatatan

dokumentasi dan observasi yang dilakukan peneliti pada tanggal 2 Desember 2019 mendapatkan hasil bahwa beberapa siswa di kelas V SD masih mengalami kesulitan dalam belajar dikarenakan kurangnya motivasi dari guru untuk mengembangkan kemampuan berpikir kritis dan literasi humanistik siswa. Dilihat dari hasil studi Program for Internasional Student Assement (PISA) siswa berpikir kritis individu Indonesia masih tergolong rendah. Berdasarkan hasil studi tersebut peringkat PISA Indonesia tahun 2018 turun apabila dibandingkan dengan hasil PISA tahun 2015. Khususnya untuk kategori kinerja sains, Indonesia berada di peringkat 5 dari bawah 77, yakni dengan rata-rata skor 396. Peringkat Indonesia berada di atas Arab Saudi yang memiliki rata-rata skor 386. Peringkat satu diduduki China dengan rata-rata skor 500 (Tohir, 2019). Selain itu juga guru masih kesulitan dalam pembuatan instrumen serta belum pernah mengembangkan instrumen dikarenakan guru hanya berpusat pada buku ajar dalam melakukan penilaian pada saat proses pembelajaran berlangsung. Sehingga itu menyebabkan siswa menjadi tidak termotivasi untuk belajar dikarenakan kurangnya penilaian yang dilakukan oleh guru. Oleh karena itu diperlukan suatu pembaharuan atau studi pengembangan instrument yang dapat menilai siswa dari segi sikap, pengetahuan, dan keterampilan siswa sehingga implementasi penilaian yang dilakukan guru menjadi lebih akurat dan tepat sasaran sehingga siswa menjadi lebih semangat dan merasa termotivasi untuk belajar dalam proses kegiatan pembelajaran berlangsung. Maka dari itu peneliti akan mengembangkan instrument untuk menilai kemampuan berpikir kritis siswa dan literasi humanistik pada pembelajaran IPA di SD.

Penilaian kemampuan berpikir kritis yang dikembangkan oleh peneliti dapat digunakan saat proses kegiatan pembelajaran berlangsung. Kemampuan berpikir kritis dapat dilatih untuk siswa dalam menganalisis sesuatu untuk menyelesaikan permasalahan. Melalui kemampuan berpikir kritis, siswa akan mampu menyelesaikan permasalahan di luar kelas seperti membandingkan sesuatu, melakukan evaluasi, dan mampu menggunakan logikanya dalam sebuah diskusi dalam masyarakat. Sedangkan penilaian kemampuan literasi humanistik siswa akan digunakan untuk menilai 
kemampuan yang dimiliki oleh siswa sehingga siswa bisa berinteraksi baik dengan lingkungannya, teman, guru, orangtua, maupun masyarakat. Dalam instrumen literasi humanistik ini akan menilai terkait dengan kemampuan komunikasi, kolabirasi, kreatif, inovatif dan berpikir kritis siswa pada saat proses kegiatan pembelajaran berlangsung.

Berdasarkan pemaparan di atas, peneliti tertarik untuk melaksanakan penelitian yang berjudul "Pengembangan Instrumen Kemampuan Berpikir Kritis dan Literasi Humanistik pada Pembelajaran IPA Kelas V SD Tahun Pelajaran 2019/2020".

\section{METODE}

Penelitian ini menggunakan model penelitian dan pengembangan pendidikan (educational research and development) yang bertujuan untuk mengembangkan intrumen kemampuan berpikir kritis dan literasi humanistic pada pembelajaran IPA kelas $\mathrm{V}$ SD. Desain penelitian ini menggunakan model pengembangan 4D (four-D). Menurut Thiagarajan et al (dalam Trianto,2012) model menelitian dan pengembangan model 4D terdiri dari 4 tahapan, yaitu; define, design, develop, dan disseminate atau dapat diadaptasi menjadi 4P, yaitu; pendefinisian, perancangan, pengembangan, dan penyebaran. Subyek pada penelitian pengembangan seperti ini dapat meliputi para ahli dan praktisi, dalam hal ini adalah 2 dosen Pendidikan Dasar dan 3 guru kelas $\mathrm{V}$ Sekolah Dasar. Dalam penelitian ini, ada dua variabel yang digunakan yaitu intrumen kemampuan berpikir kritis dan intrumen literasi humanistik pada pembelajaran IPA kelas V SD. Variabel dapat diartikan sebagai suatu totalitas gejala atau objek pengamatan yang akan diteliti (Dantes 2012). Prosedur penelitian dalam pengembangan produk instrument kemampuan berpikir kritis dan literasi humanistik kelas $\mathrm{V}$ SD adalah sebagai berikut : (a) define / Analisis kebutuhan dilakukan melalui studi literatur dan studi lapangan/ empirik. Studi literatur dilakukan untuk mengkaji standar isi kurikulum 2013.

Adapun kegiatan yang dilakukan pada studi literatur sebagai berikut :
Menganalisis standar isi (kompetensi inti dan kompetensi dasar) untuk membuat jaring tema, jaring sub tema sehingga menghasilkan intrumen kemampuan berpikir kritis dan literasi humanistik, Menyususn indikator dan dan ranah kognitif, dan studi lapangan/ empirik dilakukan dengan mengobservasi aktivitas guru dan siswa dalam pelaksanaan pembelajaran di sekolah dasar sesuai dengan kurikulum 2013. (b) Pada tahap perancangan (design) hasil-hasil yang diperoleh dari studi literatur dan studi lapangan digunakan untuk merancang intrumen kemampuan berpikir kritis dan literasi humanistik. Pada rancangan draf Intrumen ini kegiatan yang dilakukan adalah menganalisis kurikulum, pemetaan jejaring tema kelas $V$ untuk mengembangkan prototype intrumen, yang nantinya akan divalidasi oleh ahli dan validasi oleh praktisi untuk mengetahui kelemahan-kelemahan konstruks instrument kemampuan berpikir kritis dan literasi humanistik yang telah dikembangkan dan sesuai dengan masukan yang diberikan, maka dilakukan penyempurnaan untuk mendapatkan draf instrument kemampuan berpikir kritis dan literasi humanistik yaitu : Pengembangan intrumen sesuai dengan validasi ahli, Validitas ahli dilakukan untuk memastikan pengembangan instrument kemampuan berpikir kritis dan literasi humanistik sesuai dengan isi, Validasi produk instrumen oleh praktisi guru senior (ahli kurikulum), dan Revisi produk (Intrumen), (c) Tahap pengembangan (develop) produk akhir dari penelitian dan pengembangan ini adalah instrument kemampuan berpikir kritis dan hasil belajar IPA yang valid, reliabel dan relevan untuk diterapkan dalam pembelajaran (validasi skup terbatas). Hasil pengujian kemudian digunakan untuk revisi sehingga produk memenuhi kriteria kelayakan (secara teoretik) untuk diimplementasi, (d) Thiagarajan (1974: 9) membagi tahap disseminate dalam tiga kegiatan yaitu: validation testing, packaging, diffusion and adoption. Pada tahap validation testing, produk yang sudah direvisi pada tahap pengembangan 
diimplementasikan pada sasaran yang sesungguhnya.

Pada penelitian pengembangan ini teknik pengumpulan data dapat menggunakan tes essay dan teknik kuesioner atau angket. Tes dan kuesioner digunakan untuk mengukur kelayakan/ validasi dari produk telah dikembangkan. Dalam penelitian ini validitas yang diuji yaitu instrumen kemampuan berpikir kritis dan literasi humanistik diuji terlebih validasi oleh 3 praktisi dari guru SD dan 2 Pakar Dosen Pendas. Instrumen disebut valid apabila benar-benar mampu mengukur apa yang semestinya diukur dengan instrumen tersebut (Candiasa, 2010:21). Hasil validasi dari validator dianalisis menggunakan analisis Content Validity Ratio (CVR)

Ketentuan tentang indeks CVR menurut Lawshe (1975) sebagai berikut: (a) Saat jumlah responden yang menyatakan setuju atau sangat setuju kurang dari $1 / 2$ total responden maka nilai CVR = - , (b) Saat jumlah responden yang menyatakan setuju atau sangat setuju $1 / 2$ dari total responden maka nilai $\mathrm{CVR}=0$, (c) Saat seluruh responden menyatakan setuju atau sangat setuju maka nilai CVR $=1$ (hal ini diatur menjadi 0,99 disesuaikan dengan jumlah). Karena jumlah responden yang digunakan dalam penelitian ini ada 5 orang maka nilai kritis CVR $=0,99$, (d) Saat jumlah responden yang menyatakan setuju atau sangat setuju lebih dari $1 / 2$ total responden maka nilai $\mathrm{CVR}=0-0,99$. Setelah mengidentifikasi setiap sub pertanyaan instrumen dengan menggunakan CVR, maka selanjutnya yaitu menghitung $\mathrm{CVI}$ (Content Validity Index). CVI digunakan untuk menghitung rata-rata dari keseluruhan nilai CVR untuk komponen instrumen kemampuan berpikir kritis dan literasi humanistik.

Dalam penelitian ini uji reliabilitas dilakukan dengan menggunakan teknik formula alpha cronbach. menurut arikunto (2009), rumus alpha cronbach digunakan untuk mencari reliabillitas instrument yang skornya bukan 1 dan 0 , seperti angket atau soal bentuk uraian. Rumus alpha cronbach sebagai berikut.

\section{HASIL DAN PEMBAHASAN}

Hasil penelitian ini berupa suatu produk instrument kemampuan berpikir kritis dan literasi humanistik pada pembelajaran IPA untuk kelas V SD. Pada tahap develop, langkah yang dilakukan adalah membuat instrument (contructing test) dan validasi isi oleh pakar (expert appraisal). Instrumen yang dikembangkan dalam penelitian ini adalah instrumen kemampuan berpikir kritis dan literasi humanistik pada pembelajaran IPA kelas $V$ SD. Kemudian instrumen kemampuan berpikir kritis dan literasi humanistik tersebut diuji validasi oleh 5 pakar yaitu 2 ahli (dosen) dan 3 praktisi (guru). Setelah penggolongan validitas uji judges instrumen kemampuan berpikir kritis dengan 5 pakar, selanjutnya dilakukan perhitungan validitas isi dengan menggunakan rumus Lawshe.

Tabel 1. Tabel Kerja Perhitungan Validitas Content Instrumen Kemampuan Berpikir Kritis dengan 5 Pakar Menggunakan Rumus Lawshe

\begin{tabular}{ccccc}
\hline No. Butir & Relevan & Tidak relevan & CVR & Status Soal \\
\hline 1 & 5 & 0 & 1 & Valid \\
2 & 4 & 1 & 0,6 & Valid \\
3 & 5 & 0 & 1 & Valid \\
4 & 5 & 0 & 1 & Valid \\
5 & 5 & 0 & 1 & Valid \\
6 & 4 & 1 & 0,6 & Valid \\
7 & 4 & 1 & 0,6 & Valid
\end{tabular}




\begin{tabular}{ccccc}
\hline No. Butir & Relevan & Tidak relevan & CVR & Status Soal \\
\hline 8 & 5 & 0 & 1 & Valid \\
\hline 9 & 5 & 0 & 1 & Valid \\
10 & 5 & 0 & 1 & Valid \\
$\Sigma$ CVR & & & 8,8 & \\
\hline
\end{tabular}

Berdasarkan hasil uji validitas isi pengembangan produk instrumen kemampuan berpikir kritis dengan 5 pakar yakni 2 dosen ahli dan 3 praktisi (guru) menggunakan rumus lawshe mendapatkan hasil bahwa, semua butir instrument kemampuan berpikir kritis dikategorikan valid dan layak digunakan tanpa perlu direvisi kembali. Hasil perhitungan content validity index instrument kemampuan berpikir kritis yang di kembangkan mendapatkan hasil sebesar $\mathrm{CVI}=0,88$. Hal ini berarti, instrument berpikir kritis yang di kembangkan termasuk ke dalam kriteria validitas sangat tinggi. Sedangkan penggolongan validitas uji judges instrumen literasi humanistik dengan 5 pakar, dilakukan perhitungan validitas isi dengan menggunakan rumus Lawshe.

Tabel 2. Tabel kerja untuk menghitung Validitas Content Literasi Humanistik menggunakan rumus Lawshe

\begin{tabular}{ccccc}
\hline No. Butir & Relevan & Tidak Relevan & CVR & Status Soal \\
\hline 1 & 5 & 0 & 1 & Valid \\
2 & 5 & 0 & 1 & Valid \\
3 & 4 & 1 & 0,6 & Valid \\
4 & 5 & 0 & 1 & Valid \\
5 & 5 & 0 & 1 & Valid \\
6 & 4 & 1 & 0,6 & Valid \\
7 & 5 & 0 & 1 & Valid \\
8 & 5 & 0 & 1 & Valid \\
9 & 4 & 1 & 0,6 & Valid \\
10 & 4 & 1 & 0,6 & Valid \\
11 & 5 & 0 & 1 & Valid \\
12 & 5 & 0 & 1 & Valid \\
$\sum$ CVR & & & 10,4 & \\
\hline
\end{tabular}

Berdasarkan hasil uji validitas content pengembangan produk instrumen literasi humanistik dengan 5 pakar yakni 2 dosen ahli dan 3 praktisi (guru) menggunakan rumus lawshe mendapatkan hasil bahwa, semua butir instrument literasi humanistik dikategorikan valid dan layak digunakan tanpa perlu direvisi kembaali. Kemudian melakukan perhitungan content validity index instrument literasi humanistik masalah yang di kembangkan mendapatkan hasil sebesar $\mathrm{CVI}=0,86$. $\mathrm{Hal}$ ini berarti, instrument literasi humanistik yang di kembangkan termasuk ke dalam kriteria validitas sangat tinggi.

Hasil Uji reliabilitas instrumen kemampuan berpikir kritis pada pembelajaran IPA kelas V SD diuji oleh 5 pakar yaitu 2 ahli (dosen) dan 3 praktisi 
(guru). Nilai-nilai untuk pengujian reliabilitas diambil dari skor-skor item angket kemampuan berpikir kritis yang dinyatakan valid atau terpakai. Item yang tidak valid tidak dilibatkan dalam pengujian reliabilitas. Dalam hal ini semua butir tes kemampuan berpikir kritis dinyatakan valid, maka dari itu semua item butir tes kemampuan berpikir kritis dapat di uji reliabilitasnya. Uji reliabilitas instrument kemampuan berpikir kritis diuji dengan menggunakan teknik formula alpha cronbach. Menurut Arikunto (2009), rumus alpha cronbach digunakan untuk mencari reliabillitas instrumen yang skornya bukan 1 dan 0 , seperti angket atau soal bentuk uraian.

Tabel 3. Tabel kerja untuk menghitung Reliabilitas Instrumen Kemampuan Berpikir Kritis dengan 5 pakar menggunakan alpha cronbach

\begin{tabular}{|c|c|c|c|c|c|c|}
\hline \multirow{2}{*}{ No } & \multicolumn{5}{|c|}{ Pakar (Judges) } & \multirow[b]{2}{*}{ Total Skor } \\
\hline & 1 & II & III & IV & V & \\
\hline 1 & 5 & 5 & 4 & 5 & 5 & 24 \\
\hline 2 & 5 & 4 & 4 & 5 & 4 & 22 \\
\hline 3 & 4 & 3 & 4 & 5 & 3 & 19 \\
\hline 4 & 5 & 5 & 5 & 5 & 5 & 25 \\
\hline 5 & 5 & 4 & 5 & 5 & 4 & 23 \\
\hline 6 & 4 & 2 & 4 & 4 & 5 & 19 \\
\hline 7 & 5 & 3 & 4 & 4 & 4 & 20 \\
\hline 8 & 5 & 4 & 5 & 5 & 5 & 24 \\
\hline 9 & 5 & 5 & 5 & 5 & 5 & 25 \\
\hline 10 & 5 & 4 & 4 & 5 & 4 & 22 \\
\hline$\sum X$ & 48 & 39 & 44 & 48 & 44 & 223 \\
\hline $\bar{M}_{2}$ & 4.8 & 3.9 & 4.4 & 4.8 & 4.4 & 22.3 \\
\hline$\sigma \bar{b}$ & 0.16 & 0.89 & 0.24 & 0.16 & 0.44 & 4.81 \\
\hline$\sum \sigma \frac{2}{b}$ & \multicolumn{6}{|c|}{$0,16+0,89+0,24+0,16+0,44=1,89$} \\
\hline$\sigma \bar{t}$ & 4,81 & & & & & \\
\hline
\end{tabular}

Berdasarkan hasil uji reliabilitas instrumen kemampuan berpikir kritis dengan 5 pakar menggunakan rumus alpha cronbach mendapatkan hasil sebesar $r 11=0,674$. Hal ini berarti, instrument berpikir kritis pada pembelajaran IPA kelas $\mathrm{V}$ SD yang di kembangkan berada pada kriteria reliabilitas tinggi. Sedangkan Uji reliabilitas instrumen literasi humanistik pada pembelajaran IPA kelas V SD diuji oleh 5 pakar yaitu 2 ahli (dosen) dan 3 praktisi (guru). Nilai-nilai untuk pengujian reliabilitas diambil dari skor-skor item angket literasi humanistik yang dinyatakan valid atau terpakai. Item yang tidak valid tidak dilibatkan dalam pengujian reliabilitas. Dalam hal ini semua butir item rubrik penilaian literasi humanistik dinyatakan valid, maka dari itu semua item rubrik penilain literasi humanistik dapat di uji reliabilitasnya. Uji reliabilitas instrument literasi humanistik diuji dengan menggunakan teknik formula alpha cronbach. 
Tabel 4. Tabel kerja untuk menghitung Reliabilitas Instrumen Literasi Humanistik menggunakan alpha Cronbach

\begin{tabular}{ccccccc}
\hline No & \multicolumn{7}{c}{ Pakar (Judges) } & V & Total Skor \\
\hline 1 & I & II & III & IV & 5 & 24 \\
2 & 4 & 5 & 4 & 5 & 3 & 17 \\
3 & 4 & 4 & 3 & 3 & 4 & 20 \\
4 & 4 & 3 & 4 & 4 & 4 & 19 \\
5 & 5 & 4 & 5 & 3 & 4 & 21 \\
6 & 5 & 3 & 3 & 4 & 3 & 23 \\
7 & 5 & 5 & 5 & 3 & 5 & 22 \\
8 & 5 & 4 & 4 & 5 & 5 & 24 \\
9 & 5 & 4 & 5 & 5 & 5 & 24 \\
10 & 5 & 4 & 5 & 5 & 5 & 25 \\
11 & 5 & 5 & 5 & 5 & 5 & 263 \\
12 & 5 & 5 & 5 & 5 & 5 & 21.916 \\
$\sum \mathrm{X}$ & 57 & 50 & 53 & 50 & 53 & 6.5763 \\
$\mathrm{M}$ & 4.75 & 4.1666 & 4.4166 & 4.1666 & 4.4166 & \\
$\sigma \frac{2}{b}$ & 0.1875 & 0.4722 & 0.5763 & 0.8055 & 0.5763 & \\
$\sum \sigma \frac{2}{b}$ & $0,18+0,47+0,57+0,80+0,57=2,61$ & & \\
$\sigma \frac{2}{t}$ & 6,57 & &
\end{tabular}

Berdasarkan hasil uji reliabilitas instrumen literasi humanistik dengan 5 pakar menggunakan rumus alpha cronbach mendapatkan hasil sebesar $\mathrm{r} 11$ $=0,656$. Hal ini berarti, instrument literasi humanistik pada pembelajaran IPA kelas V SD yang di kembangkan berada pada kriteria reliabilitas tinggi.

Pertama, Validasi intrumen kemampuan berpikir kritis ditempuh melalui dua tahapan validasi yaitu validasi ahli dan praktisi. Validasi dilakukan oleh 2 orang pakar yang berasal dari kalangan dosen yang berkompeten di bidangnya dan 3 orang praktisi yang berasal dari guru kelas V SD. Tujuan dilakukan uji validasi isi ini untuk mengetahui valid tidaknya butir instrumen kemampuan berpikir kritis yang di kembangkan serta tingkat kevalidan dari keseluruhan butir tes esay kemampuan berpikir kritis. Berdasarkan hasil analiss uji validitas isi menggunakan rumus lawshe mendapatkan hasil bahwa seluruh butir instrument kemampuan berpikir kritis dinyatakan valid dengan rata-rata CVR sebesar 8,8. Setelah rata-rata CVR instrument kemampuan literasi didapat selanjutnya dilakukan perhitungan content valitidy index (CVI) mendapatkan hasil sebesar 0,88 , selanjutnya hasil tersebut dikonversikan kedalam table kriteria validasi isi instrument kemampuan berpikir kritis berada pada kriteria validitas sangat tinggi. Berdasarkan hasil uji validitas isi intrumen tersebut dapat dikatakan bahwa instrumen kemampuan berpikir kritis pada pembelajaran IPA kelas V SD tergolong ke dalam validitas sangat tinggi dan layak digunakan di SD.

Hasil ini sejalan dengan penelitian yang dilakukan oleh Trimawati, dkk (2020) dengan hasil penelitiannya menunjukkan bahwa : (a) perangkat pembelajaran dan instrumen penilaian IPA Terpadu yang dikembangkan berkategori sangat valid dengan nilai modus 5, (b) kegiatan pembelajaran terlaksana sangat baik dengan nilai modus 5, (c) aktivitas siswa dalam pembelajaran terlaksana sangat baik dengan nilai modus 5, (d) respon siswa terhadap pembelajaran proyek 
cukup baik dengan kisaran angka antara $50 \%-60 \%$, dan (e) hasil tes berpikir kritis dan kreatif siswa ada peningkatan yang baik pula, kemampuan berpikir kritis meningkat dari 25,85 (Kurang Kritis) menjadi 87,76 (Sangat Kritis) dan kemampuan berpikir kreatif meningkat dari 20,44 (Kurang Kreatif) menjadi 84,85 (Sangat Kreatif). Simpulan pengembangan perangkat pembelajaran dan instrumen penilaian IPA Terpadu dalam pembelajaran Project Based Learning yang dikembangkan layak digunakan untuk meningkatkan kemampuan berpikir kritis dan kreatif siswa. Hasil yang diperoleh instrumen kemampuan berpikir kritis di kelas $\mathrm{V}$ yang sangat baik dan layak digunakan disebabkan oleh beberapa faktor. Produk instrumen kemampuan berpikir kritis sesuai dengan aspek pengukuran validitas yaitu validitas isi. Produk intsrumen memenuhi validitas isi berarti dalam pengembangannya telah didasari atas teori-teori yang dijadikan acuan dalam penyusunan. Sedangkan produk instumen yang memenuhi validitas konstruk berarti dalam pengembangannya memperhatikan keterkaitan antara materi, dan aspek kemampuan berpikir kritis. Hal tersebut dapat mengarahkan siswa untuk mampu memahami materi atau konsep yang dipelajari, dan meningkatkan kemampuan berpikir. Selain itu intrumen berfungsi untuk memahami dan mengarahkan potensi dari seorang peserta didik agar dapat menggali terus potensinya dan memperbaiki kelemahannya. Tujuan utama kurikulum adalah untuk mempersiapkan peserta didik agar dapat menjadi pribadi serta warga negara yang kreatif, inovatif, beriman, dan juga afektif ketika dia berada pada lingkungan masyarakat kelak. Faktor-faktor tersebut diatas menyebabkan produk instrumen kemampuan berpikir kritis yang dikembangkan sudah memenuhi kriteria sangat baik sesuai dengan yang diharapkan, baik dari segi isi dan konstruk sehingga sangat layak untuk digunakan di SD. Reliabilitas instrumen mengacu pada konsistensi hasil pengukuran yang ditunjukkan oleh instrumen tersebut. Instrumen yang memiliki reliabiltas yang tinggi akan memberikan hasil yang relatif sama, sekalipun instrumen tersebut digunakan dalam kurun waktu yang berbeda. Reliabilitas instrumen kemampuan berpikir kritis dilakukan dengan formula Alpha Cronbach karena pada dasarnya formula Alpha Cronbach lebih umum diterapkan untuk menghitung reliabilitas tes politomi. Sejalan dengan Arikunto (2009), rumus Alpha Cronbach digunakan untuk mencari reliabillitas instrumen yang skornya bukan 1 dan 0 , seperti angket atau soal bentuk uraian. Berdasarkan hasil uji reliabilitas instrumen kemampuan berpikir kritis dengan 5 pakar menggunakan rumus alpha cronbach mendapatkan hasil sebesar $\mathrm{r} 11=0,674$ dengan kategori tinggi.

Kedua, hasil uji validitas isi instrument literasi humanistik di validasi oleh 5 pkar yaitu 2 dosen ahli dan 3 praktisi dari guru SD. Tujuan dilakukan uji validasi isi ini untuk mengetahui valid tidaknya butir intrumen yang di kembangkan serta tingkat kevalidan dari keseluruhan butir rubrik literasi humanistik. Jumlah butir rubrik instrumen humanistik yang dikembangkan berjumlah 12 butir. Berdasarkan hasil analisis uji validitas isi menggunakan rumus lawshe mendapatkan hasil bahwa seluruh butir rubrik instrument literasi humanistik dinyatakan valid dengan rata-rata CVR sebesar 10,4. Setelah rata-rata CVR instrument kemampuan literasi didapat selanjutnya dilakukan perhitungan content valitidy index (CVI) mendapatkan hasil sebesar 0,86, kemudian hasil tersebut dikonversikan kedalam table kriteria validasi isi instrument kemampuan literasi humanistik berada pada kriteria validitas sangat tinggi. Berdasarkan hasil uji validitas isi intrumen tersebut dapat dikatakan bahwa instrumen literasi humanistik pada pembelajaran IPA kelas V SD tergolong kedalam validitas sangat tinggi dan layak digunakan di sekolah dasar. Hasil ini sejalan dengan penelitian yang dilakukan oleh Sanjayanti, N.P.A.H dkk (2018) dengan hasil penelitiannya menunjukkan bahwa koefisien parsial antara variabel $X 1$ dengan variabel $Y$ memiliki nilai 0,663 dan nilai $r 2=0,4396$ (44\%). Ini berarti bahwa literasi humanistik 
(X1) berdeterminasi sebesar 44\% terhadap kualitas model pembelajaran konstruktivis $(Y)$. Kecendrungan klasifikasi data literasi humanistik mahasiswa sekolah dilakukan dengan menghitung mean ideal (Mi) dan standar deviasi ideal (Sdi) dimana $\mathrm{Mi}=1 / 2 \times$ (skor maksimal + skor minimal) dan Sdi $=1 / 6$ (skor maksimal - skor minimal). Jika dilihat dari rata-rata (mean) = 93,39 dan dikonversikan ke dalam tabel, dapat diketahui bahwa kencederungan data literasi humanisik dalam kategori tinggi.

Adanya instrumen kemampuan literasi humanistik berupa rubrik penilaian yang baik sangat diperlukan agar dapat mengukur kemampuan siswa dilihat dari aspek kreatif, pemikiran kritis, komunikatif, dan kolaboratif. Penilaian jika diterapkan dengan benar dapat meningkatkan kulitas pembelajaran. Hasil dari penilaian dapat meningkatkan validitas interpretasi guru terhadap siswa sehingga dalam hal ini instrumen literasi humanistik berpengaruh terhadap peningkatan kualitas pembelajaran. Instrumen yang baik dan layak digunakan harus sudah divalidasi. Tujuan dari validasi adalah untuk mendapatkan umpan balik, kritik dan saran tentang peningkatan kualitas produk sesuai dengan keahlian pelaku validasi. Validasi ahli bertujuan untuk memberikan penilaian terhadap item dalam instrumen. Sehingga instrumen yang sudah divalidasi dapat dikatakan layak digunakan di Sekolah Dasar. Uji reliabilitas instrumen literasi humanistik dilakukan setelah melakukan uji validitas isi terlebih dahulu. Nilai pengujian reliabilitas diambil dari rubrik penilaian instrumen literasi humanistik yang dinyatakan valid atau terpakai. Dalam hal ini semua rubrik penilaian instrumen literasi humanistik dinyatakan valid, maka dari itu semua rubrik penilaian instrumen literasi humanistik dapat di uji reliabilitasnya.

Uji reliabilitas instrument literasi humanistik diuji oleh 5 pakar yaitu 2 dosen ahli dan 3 praktisi dari guru. Instrument kemampuan pemecahan masalah di uji reliabilitasnya menggunakan rumus formula alpha Cronbach. Rumus alpha cronbach digunakan untuk mencari reliabillitas instrument dengan skor bukan
1 dan 0 , seperti angket atau soal bentuk uraian. Berdasarkan bentuknya instrument literasi humanistik yang di kembangkan berbentuk rubrik penilaian dengan teknik penskoran menggunakan skala liket dengan rentangan skor 1 sampai 5 . Berdasarkan hasil uji reliabilitas instrumen literasi humanistik dengan 5 pakar menggunakan rumus alpha cronbach mendapatkan hasil sebesar $r 11=0,656$. Hal ini berarti, instrument literasi humanistik pada pembelajaran IPA kelas V SD yang di kembangkan berada pada kriteria reliabilitas tinggi . Instrumen yang mempunyai tingkat reliabilitas tinggi layak digunakan di SD. Berdasarkan hasil paparan tersebut, instrumen rubrik penilaian yang telah dikembangkan dapat digunakan untuk mengukur kemampuan literasi humanistik siswa pada pembelajaran IPA kelas V SD.

\section{PENUTUP}

Berdasarkan laporan hasil penelitian seperti yang telah dipaparkan pada bagian sebelumnya, maka dapat disimpulkan beberapa hasil penelitian sebagai berikut : (1) Instrumen kemampuan berpikir kritis yang dikembangkan memenuhi syarat validitas konten dengan nilai 0,88 dengan kategori sangat baik dan sangat layak digunakan, (2) Instrumen literasi humanistik yang dikembangkan memenuhi syarat validitas konten dengan nilai 0,86 dengan kategori sangat baik dan sangat layak digunakan, (3) Instrumen berpikir kritis yang dikembangkan memenuhi syarat reliabilitas expert dengan nilai 0,674 dengan kategori tinggi sehingga layak digunakan dalam pembelajaran, (4) Instrumen literasi humanistik yang dikembangkan memenuhi syarat reliabilitas expert dengan nilai 0,656 dengan kategori tinggi sehingga layak digunakan dalam pembelajaran.

Mengacu pada rumusan masalah dan didukung oleh laporan hasil penelitian dalam penelitian ini, dapat diajukan saran sebagai berikut.

Adapun beberapa saran yang dapat disampaikan dalam penelitian pengembangan ini guna peningkatan kualitas instrumen kemampuan berpikir kritis dan literasi humanistik dalam 
pembelajaran IPA sebagai berikut :a)Bagi Guru, diharapkan dapat lebih berinovasi dalam pembuatan instrumen untuk alat penilaian pada proses pembelajaran kepada siswanya dan memanfaatkan instrumen ini untuk meningkatkan kemampuan berpikir kritis dan literasi humanistik siswa pada pembelajaran IPA serta untuk meningkatkan kemampuan profesional guru dalam pembuatan instrument, b)Bagi Kepala Sekolah, diharapkan dapat mengambil kebijakan untuk mengembangkan instrumen kemampuan berpikir kritis dan literasi humanistik yang dapat disesuaikan dengan kurikulum yang diterapkan di sekolah, c)Bagi Peneliti lain diharapkan hasil penelitian ini dapat dijadikan sebagai acuan kepustakaan untuk melakukan penelitian ini, penelitian lanjutan, penelitian perbandingan baik dalam variabel yang sama ataupun yang berbeda.

\section{DAFTAR RUJUKAN}

Azwar, Saifuddin. 2013. Reliabilitas dan Validitas. Yogyakarta: Pustaka Pelajar

Arikunto, Suharsimi. 2009. Dasar-Dasar Evaluasi Pendidikan. Jakarta: PT Bumi Aksara.

Candiasa, I Made. 2010. Statistik Multivariat Disertai Petunjuk analisis SPSS. Singaraja : Universitas Pendidikan Ganesha.

Dantes, Nyoman. 2017a. Pedagogik Dalam Perspektif. Singaraja: Undiksha Press.

Dantes, Nyoman. 2017b. Analisis Dan Desain Eksperimen. Depok: PT.Raja Grafindo Persoda.

Koyan, I. Wayan. 2012. Statistik Pendidikan Teknik Analisis Data Kuantitatif. Singaraja: Universitas Pendidikan Ganesha Pers.

Lawshe, C H. A. 1975. Quantitative Approach To Content Validity. state university : A paper presented at content validity, a conference helt at Bowling green, state university
Sanjayanti, N.P.A.H ,dkk. 2018. "Diagnosa Literasi Humanistik dalam Model Pembelajaran Kontruktivis pada Mahasiswa Politeknik Ganesha Guru". Seminar Nasional Riset Inovatif. Prodi Pendidikan Fisika Muhamaddiyah Mataram. Diakses tanggal 24 juni 2019. http://eproceeding.undiksha.ac.id/ind ex.php/senari/arti/cie/view/1548

Undang-Undang Republik Indonesia Nomor 20 Tahun 2003 tentang Sistem Pendidikan Nasional. 2003. Jakarta: Kementerian Pendidikan Nasional.

Supriyadi. 2009. IPA Dasar. Yogyakarta : FMIPA UNY

Susanto, Ahmad. 2013. Teori Belajar dan Pembelajaran Di Sekolah Dasar. Jakarta: Kencana Prenadamedia.

Roestiyah. 2008. Strategi Belajar Mengajar. Jakarta: PT Rineka Cipta.

Tohir, Mohammad. 2019. Hasil PISA Indonesia 2018 turun dibandingkan tahun 2015. Situbondo

Trianto. 2012. Model Pembelajaran Terpadu. Jakarta : Bumi Aksara.

Thiagarajan, Sivasailam, dkk. 1974. Intructional Development for Training Teachers of Exceptional Children. Washinton DC: National Center for Improvement Educational System. 